\title{
Screening The Effect of $\mathrm{Cu}, \mathrm{Mn}$, and $\mathrm{Mg}$ on Ethanol Formation in Degradation Process of Palm Oil Mill Effluent (POME) under Anaerobic Condition Using Two-Level Factorial Design Method
}

\author{
Tia Widya Puteri ${ }^{1 *}$ and Mindriany Syafila ${ }^{2}$ \\ ${ }^{1}$ Department of Environmental Engineering, Institut Teknologi Bandung, 40132 Bandung, Indonesia \\ ${ }^{2}$ Department of Environmental Engineering, Institut Teknologi Bandung, 40132 Bandung, Indonesia
}

\begin{abstract}
Anaerobic digestion can be used for the treatment of POME to reduce organic content and generate some substances, such as volatile acids, ethanol, and various gasses. During anaerobic fermentation process, microorganism requires the presence of trace elements for growth to improve their performance. This research will be carried out as a study of the presence of trace elements, such as metals $\left(\mathrm{Cu}^{2+}, \mathrm{Mn}^{2+}\right.$, and $\left.\mathrm{Mg}^{2+}\right)$ that has significant effects on ethanol formation. Circulating Bed Reactor was used and operated in a batch system for 48 hours. Metal ions were screened and analyzed by using two-level factorial design method whether there is any correlation effect between the addition of $\mathrm{Cu}^{2+}, \mathrm{Mn}^{2+}$, and $\mathrm{Mg}^{2+}$ and ethanol formation. Several parameters which consists of Total Volatile Acids (TVA), dissolved Chemical Oxygen Demand (CODs), Volatile Suspended Solid (VSS), pH, Dissolved Oxygen (DO), and ethanol were measured every sampling. Mn metal is proven statistically affect both TVA and ethanol formation while $\mathrm{Mg}$ metal only affect TVA formation. $\mathrm{Cu}^{2+}$ and $\mathrm{Mg}^{2+}$ metals combination affect ethanol formation with largest detected ethanol concentration is $7,483.07 \mathrm{mg} / \mathrm{L}$. The result from this study had identified the metal ions which has significant effect as a foundation for optimization ethanol formation.
\end{abstract}

\section{Introduction}

The energy used today almost entirely fossil-derived oil was known as non-renewable energy. As the production of energy from these fuels is associated to resource depletion, the identification of new and renewable sources of energy has become a matter of priority in many countries. One of those alternative energy is a biofuel derived from biomass conversion. Alternative energy can be obtained by using various types of substrates, such as raw materials containing saccharides (sugar cane, molasses), starch (corn, wheat, potatoes, tubers), dan biomass cellulose (wood, agricultural waste, agri-industrial waste) [17] that will process by anaerobic fermentation. The use of substrate selection based on availability of resources, economic efficiency considerations, as food materials availability, and other factors.

Palm oil is one of the biggest agricultural products produced in Indonesia. Oil palm is the only fruit that can give two types of oil, extracted from the fruit of the oil palm (crude palm oil, CPO) which are chemically different. Palm oil comes from the mesocarp (flesh of the fruit) and the lauric palm kernel oil from the kernel at the fruit's core (crude palm kernel oil, CPKO). The two oils are separated in the oil palm bunches by the thick shell of palm kernels. The world demand for palm oil has increased in the past few decades [25]. It causes the oil palm industry to increase production capacity to meet the demand. Along with the increased in the palm oil production, it will also generate in contaminant the production of waste. There were some types of wastes produced in this process, which are solid, air, and liquid waste. The liquid waste was known as palm oil mill effluent (POME).

POME is one of fermentation media that can be used as a substrate to produce some products, such as ethanol, total volatile acids. POME containing carbohydrate, protein, nitrogen compounds, oil and grease, highly mineral content [15], and other organic compounds, such as cellulose, hemicellulose, and starch. POME also containing 700-2.300 mg/L of starch, $1.500-3.000 \mathrm{mg} / \mathrm{L}$ of total sugar, $28.100-30.300 \mathrm{mg} / \mathrm{L}$ of carbohydrates, $4.200-6.000 \mathrm{mg} / \mathrm{L}$ of protein, $6.000-7.000 \mathrm{mg} / \mathrm{L}$ of oil and grease [23]. COD concentration in POME is 50.000 $\mathrm{mg} / \mathrm{L}$ (Ma, 2000). According to Perez et al. [19], high level of organic contents in POME can be reduced by anaerobic treatment. The processing of wastewater with high organic concentration can be treated with the suspended growth in anaerobic reactors [24].

Anaerob fermentation process will produced some substances, such as ethanol and methane gas that can be alternative energy sources. Ethanol can be produced through the pathway in fermentation process involves at least the following stages: hydrolysis, fermentation, distillation, and dehydration. Ethanol formation under anaerobic condition was caused by the presence of

\footnotetext{
* Corresponding author: tiawidyap@students.itb.ac.id
} 
decarboxylase pyruvate and dehydrogenase alcohol enzyme in acidogenesis phase.

Anaerobic fermentation process involves cell metabolism influenced by micronutrients, such as cofactor metal ions for enzyme catalyst eventhough the amount of it is low concentration. As a biological process, fermentation is highly dependent on several factors, including $\mathrm{pH}$, oxygen and temperature, which can greatly influence the specific rate of growth, and presence of enzyme modulator [9]. Metal ions can affect the rate of glycolysis phase and the conversion phase of pyruvic acid into ethanol and other organic acids [8]. Ethanol formation in the reactor was influenced by the presence of metal cofactors as trace elements especially on enzyme forming. This research will be carried out as a study of the presence of trace element, such as metals $\left(\mathrm{Cu}^{2+}, \mathrm{Mn}^{2+}\right.$, and $\mathrm{Mg}^{2+}$ ) that had the most influence on ethanol formation from palm oil mill effluent using two-way level factorial design.

\section{Materials and Methods}

\subsection{Compositions of Wastewater}

Substrate which used in this study was artificial POME, but the characterization of POME was also conducted. Characteristics of POME that analyzed was derived from PT Condong Garut, Garut Selatan, Kabupaten Garut, Jawa Barat. The characteristics of POME can be seen in Table 1.

Table 1. Characteristics of POME [14].

\begin{tabular}{|c|c|c|c|}
\hline Parameters & Unit & Methods & Value \\
\hline $\begin{array}{c}\text { Dissolved } \\
\text { COD }\end{array}$ & $\mathrm{mg} / \mathrm{L}$ & $\begin{array}{c}\text { SMEWW } \\
5220-\mathrm{B}\end{array}$ & 17,300 \\
\hline Total COD & $\mathrm{mg} / \mathrm{L}$ & $\begin{array}{c}\text { SMEWW } \\
5220-\mathrm{B}\end{array}$ & 24,500 \\
\hline BOD & $\mathrm{mg} / \mathrm{L}$ & $\begin{array}{c}\text { SMEWW } \\
5210-\mathrm{B}\end{array}$ & 12,450 \\
\hline Oil and grease & $\mathrm{mg} / \mathrm{L}$ & $\begin{array}{c}\text { SMEWW } \\
5520-\mathrm{D}\end{array}$ & 185 \\
\hline $\mathrm{pH}$ & - & $\begin{array}{c}\text { SMEWW } \\
4500-\mathrm{H}^{+}-\mathrm{B}\end{array}$ & 5.85 \\
\hline Total nitrogen & $\mathrm{mg} / \mathrm{L}$ & $\begin{array}{c}\text { SMEWW } \\
4500-N o r g-B\end{array}$ & 250 \\
\hline TSS & $\mathrm{mg} / \mathrm{L}$ & $\begin{array}{c}\text { SMEWW } \\
2540-\mathrm{D}\end{array}$ & 15,000 \\
\hline
\end{tabular}

Artificial wastewater was used as a substitute for palm oil mill effluent. Artificial wastewater was made with such characteristic of the original wastewater. This wastewater can be used as a substrate or media in anaerobic process. The artificial wasterwater compositions can be seen in Table 2 .

Table 2. Compositions of artificial wastewaster [1].

\begin{tabular}{|c|c|c|c|}
\hline Components & $\begin{array}{c}\text { concentration } \\
(\mathbf{m g} / \mathbf{L})\end{array}$ & Components & $\begin{array}{c}\text { concentration } \\
\text { (mg/L) }\end{array}$ \\
\hline Pati & 2,000 & $\mathrm{CdCl}_{2} 6 \mathrm{H}_{2} \mathrm{O}$ & 0.00003 \\
\hline Gelatin & 3,000 & $\mathrm{NaHCO}_{3}$ & 0.1571 \\
\hline Minyak-lemak & 6,000 & $\mathrm{MnCl}_{2} 6 \mathrm{H}_{2} \mathrm{O}$ & 0.0140 \\
\hline $\mathrm{NH}_{4} \mathrm{HCO}_{3}$ & 39.5 & $\mathrm{ZnCl}_{2} 6 \mathrm{H}_{2} \mathrm{O}$ & 0.0056 \\
\hline $\mathrm{K}_{2} \mathrm{HPO}_{4}$ & 0.6743 & $\mathrm{CuCl}_{2} 6 \mathrm{H}_{2} \mathrm{O}$ & 0.0047 \\
\hline $\mathrm{FeCl}_{3} 6 \mathrm{H}_{2} \mathrm{O}$ & 0.5661 & $\mathrm{CoCl}_{2} 6 \mathrm{H}_{2} \mathrm{O}$ & 0.0020 \\
\hline $\mathrm{MgCl}_{2} 6 \mathrm{H}_{2} \mathrm{O}$ & 2 & $\mathrm{CrCl}_{2} 6 \mathrm{H}_{2} \mathrm{O}$ & 0.00078 \\
\hline $\mathrm{CaCl}_{2} 6 \mathrm{H}_{2} \mathrm{O}$ & 17.21 & & \\
\hline
\end{tabular}

\subsection{Seeding and Acclimatization}

Seeding aims for duplicates the microorganism to be used in the treatment process. Biomass was used derived from biomass which had acclimatization phase in the previous study was conducted by Andrio [1]. Seeds in that process of seeding drawn from mixed cultures of microorganisms contained in cow's rumen and sludge from WWTP of palm oil industry at ratio $1: 1$. Seeding process is done by batch system in a volume reactor of $20 \mathrm{~L}$ with given glucose of 10 grams, nutrient, trace elements which consists of $\mathrm{NH}_{4} \mathrm{HCO}_{3}, \mathrm{~K}_{2} \mathrm{HPO}_{4}, \mathrm{FeCl}_{3}$, $\mathrm{MgCl}_{2}, \mathrm{CaCl}_{2}, \mathrm{NaHCO}_{3}, \mathrm{CdCl}_{2}, \mathrm{MnCl}_{2}, \mathrm{ZnCl}_{2}, \mathrm{CuCl}_{2}$, $\mathrm{CoCl}_{2}, \mathrm{CrCl}_{2}$., $\mathrm{N}_{2}$ flushing to remove oxygen.

Acclimatization is a step to adapts microorganism ability to treat POME into fermentation products. The substrate which used was artificial POME with COD concentration of $6,900 \mathrm{mg} / \mathrm{L}$. Acclimatization was conducted in three phases in a batch. Ratio of glucose solution with artificial POME each phase was 30:70 for the first phase and 70:30 for the second phase. Acclimatization process is adding $2 \mathrm{~L}$ of biomass from seeding process and $8 \mathrm{~L}$ of a mixture glucose solution and aritificial wastewater.

\subsection{Running Reactors}


Circulating Bed Reactor (CBR) is made from flexyglass with diameter of $13.5 \mathrm{~cm}$, a high of $43 \mathrm{~cm}$ and capacity

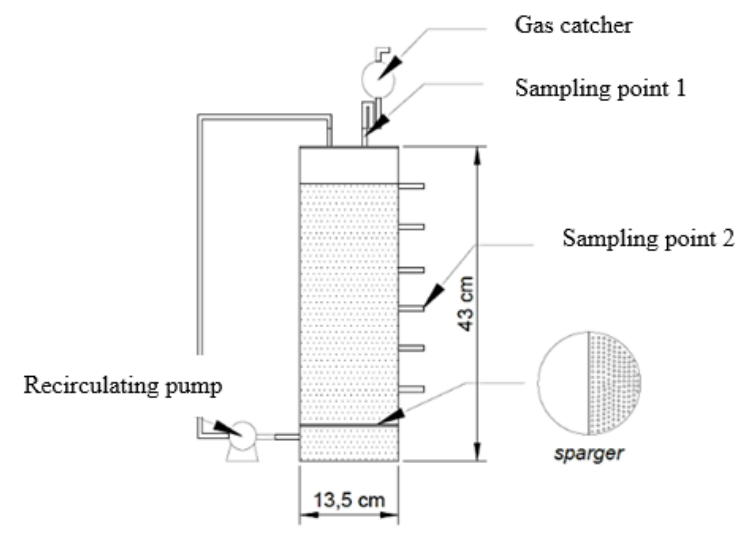

Fig. 1. Circulating Bed Reactor

of \pm 6 L. Reactor equipped with a flexyglass disc (circular with a diameter equal to the diameter of the reactor) that given the holes in half the area of the circle area, aerator, sparger and silicon hoses. The pictures of the reactor CBR can be seen in Fig. 1.

This research used two Circulating Bed Reactors that has a volume operation of 3,5 L. Ratio of biomass and artificial wastewater at 1:4 (0,7 liters to 2,8 liters of biomass and artificial wastewater). A mixture of biomass and wastewater was added phosphate buffer solution to maintain neutral condition of $\mathrm{pH}$. Each the time of operations, two reactors were operated at one variation of experimental design according to Table 5. The addition of metals in soluble form was done when mixed biomass with artificial wasterwater before it was operated in a batch reactor for 48 hours. $\mathrm{Cu}, \mathrm{Mn}$, and $\mathrm{Mg}$ metal ions were used in the study as $\mathrm{CuCl}_{2} \cdot \mathrm{H}_{2} \mathrm{O}$, $\mathrm{MnSO}_{4} \cdot \mathrm{H}_{2} \mathrm{O}$, and $\mathrm{MgCl}_{2} \cdot 6 \mathrm{H}_{2} \mathrm{O}$ with the concentration of those metals has been determined according to other researches. Concentration of metals can be seen in Table 3.

Table 3. Concentration of metals [21], [20].

\begin{tabular}{|c|c|c|}
\hline Code & Metal & $\begin{array}{c}\text { Concentration } \\
(\mathbf{m g} / \mathbf{L})\end{array}$ \\
\hline $\mathrm{A}$ & $\mathrm{Cu}$ & 0.1 \\
\hline $\mathrm{B}$ & $\mathrm{Mn}$ & 3 \\
\hline $\mathrm{C}$ & $\mathrm{Mg}$ & 0.05 \\
\hline
\end{tabular}

The reactor was operated in a batch for 48 hours at laboratory conditions with a temperature of $25-27^{\circ} \mathrm{C}$. Sampling for both reactors was conducted at the same time per 12 hours routinely. At the beginning of process, $\mathrm{N}_{2}$ flushing was given for 15 minutes about $750 \mathrm{~mL} / \mathrm{min}$. The reactors will be connected to the aerator double port in order to air re-circulate inside the reactor with a flowrate about $1 \mathrm{~L} / \mathrm{min}$. This process is expected the substrate mixed completely.

\subsection{Analytical methods}

The measurement parameters in this study consists of COD, Volatile Suspended Solid (VSS), ethanol, $\mathrm{pH}$, and Total Volatile Acids (TVA). Table 4 contains the measurement parameters with their standard analysis method.

Table 4. Analytical methods.

\begin{tabular}{|c|c|c|}
\hline No & Parameters & Analytical methods \\
\hline 1. & $\mathrm{pH}$ & $\mathrm{pH}$ meter (SM 4500 $\left.\mathrm{H}^{+}\right)$ \\
\hline 2. & COD & Dichromate COD (SM 5220C) \\
\hline 3. & VSS & Gravimeter (SM 2540 E) \\
\hline 4. & TVA & Distillation (SM 5560 C) \\
\hline 5. & Etanol & Refraktometer \\
\hline
\end{tabular}

\subsection{Experimental design}

Two-way level factorial design was used to estimate main effects in the case of two level factorial experiments using very few runs. In addition, this factorial design can also estimate the interaction of several combined factors. For each variable, the presence and absence levels of variables were tested (all trials were performed in duplicate), resulting in 8 of independent experiments (Table 5). This study was used three factors which consists of $\mathrm{Cu}^{2+}, \mathrm{Mn}^{2+}$, and $\mathrm{Mg}^{2+}$. These three factors had two levels, had siginificant effect (1) and had no significant effect (0). Concentration $(\mathrm{mg} / \mathrm{L})$ was used for $\mathrm{Cu}^{2+}, \mathrm{Mn}^{2+}$, and $\mathrm{Mg}^{2+}$ of $0.1 ; 3$; and 0.05 respectively. The metal ions were screened to determine their effects on ethanol formation.

Table 5. Experimental design factorial $2^{\mathrm{n}}$.

\begin{tabular}{|c|c|c|c|c|c|}
\hline No & \multicolumn{2}{|c|}{ Variation } & A & B & C \\
\hline 1 & 1 & 1 & 0 & 0 & 0 \\
\hline 2 & $\mathrm{~A}$ & $\mathrm{Cu}$ & 1 & 0 & 0 \\
\hline 3 & $\mathrm{~B}$ & $\mathrm{Mn}$ & 0 & 1 & 0 \\
\hline
\end{tabular}




\begin{tabular}{|c|c|c|c|c|c|}
\hline No & \multicolumn{2}{|c|}{ Variation } & A & B & C \\
\hline 4 & $\mathrm{AB}$ & $\mathrm{CuMn}$ & 1 & 1 & 0 \\
\hline 5 & $\mathrm{C}$ & $\mathrm{Mg}$ & 0 & 0 & 1 \\
\hline 6 & $\mathrm{AC}$ & $\mathrm{CuMg}$ & 1 & 0 & 1 \\
\hline 7 & $\mathrm{BC}$ & $\mathrm{MnMg}$ & 0 & 1 & 1 \\
\hline 8 & $\mathrm{ABC}$ & $\mathrm{CuMnMg}$ & 1 & 1 & 1 \\
\hline
\end{tabular}

\section{Result and Discussion}

\subsection{Characterization of artificial wastewater}

Artificial wastewater was made from a mixture of starch as carbohydrates content, peptone as a source of protein, cooking oils as the content of oil and grease, and trace elements (Table 2). All of those substances is mixed in distilled water. Artificial wastewater was processed using Circulating Bed Reactor (CBR) with the addition of trace elements under anaerobic conditions. The result of the characteristics of artificial wastewater can be seen in Table 6.

Table 6. Characteristic of artificial wastewater.

\begin{tabular}{|c|c|c|}
\hline Parameters & Unit & Value \\
\hline COD & $\mathrm{mg} / \mathrm{L}$ & 6,818 \\
\hline Dissolved COD & $\mathrm{mg} / \mathrm{L}$ & 8,515 \\
\hline BOD & $\mathrm{mg} / \mathrm{L}$ & 4,750 \\
\hline Oil and grease & $\mathrm{mg} / \mathrm{L}$ & 4,210 \\
\hline $\mathrm{pH}$ & - & 6.52 \\
\hline TVA & $\mathrm{mg} / \mathrm{L}$ & 150.4 \\
\hline TSS & $\mathrm{mg} / \mathrm{L}$ & 1,811 \\
\hline VSS & $\mathrm{mg} / \mathrm{L}$ & 1,630 \\
\hline
\end{tabular}

\subsection{Running Reactor}

$\mathrm{pH}$ values, COD removal, and biomass growth, were analyzed as process control in reactor operation. Anaerobic digestion requires an interaction between fermentative and methanogenic organisms that are sensitive to the low $\mathrm{pH}$ values. Changes in the operating conditions of the reactor or the presence of toxic compounds can cause an imbalance in the process and the accumulation of total volatile acids. The $\mathrm{pH}$ value during operation has an important role to determine the composition of the acidogenesis effluent in the reactor. The optimum $\mathrm{pH}$ for acidogenesis phase is found between 6.0 to 6.5 to avoid the formation of excess propionic acid. However, when the $\mathrm{pH}$ values as low as 4.5, $\mathrm{CO}_{2}$ and $\mathrm{H}_{2}$ are also produced with butyric and acetic acid also ethanol. Shen, et al. [21] has studied that acidogenesis phase will reach a maximum at 48-72 hours. Fig. 2 shows the $\mathrm{pH}$ values over 48 hours of reactor operation for each addition of the metal cofactors

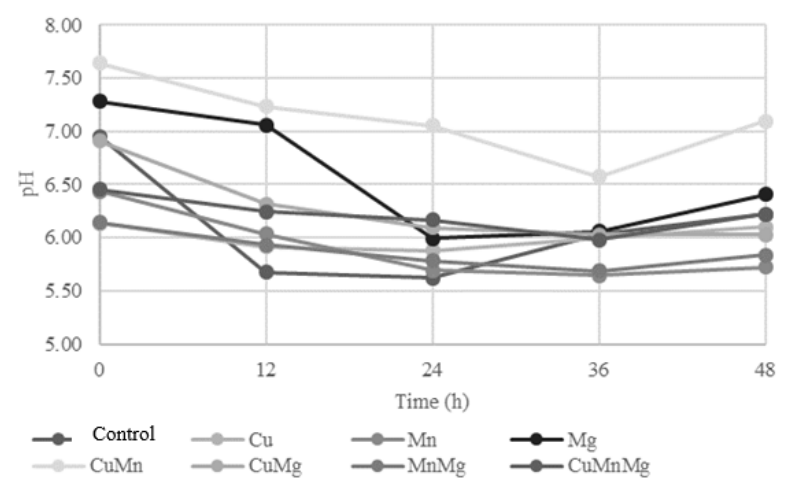

as trace element.

Fig. 2. $\mathrm{pH}$ values on operation of reactor

Based on Fig. 2 the $\mathrm{pH}$ values decrease at $36 \mathrm{~h}$ and then begin to increase at $48 \mathrm{~h}$. A decrease the $\mathrm{pH}$ values at 12 $\mathrm{h}$ showed acidogenesis phase that began to occur in the reactor, the $\mathrm{pH}$ range between 5.6 and 7.2. $\mathrm{pH}$ values still decreasing at $24 \mathrm{~h}$, the $\mathrm{pH}$ range between 5.5 and 7.2. The increase $\mathrm{pH}$ value that began at $36 \mathrm{~h}$ nearly in all reactors indicate that domination acidogenesis phase in the reactor is slowly decreased and shifted to the next phase, methanogenesis.

Biomass growth was known approximately by volatile suspended solid measurement. VSS measurement to approximate the amount of microorganism which involves in running reactor process. VSS values in this study can be seen in Fig. 3.

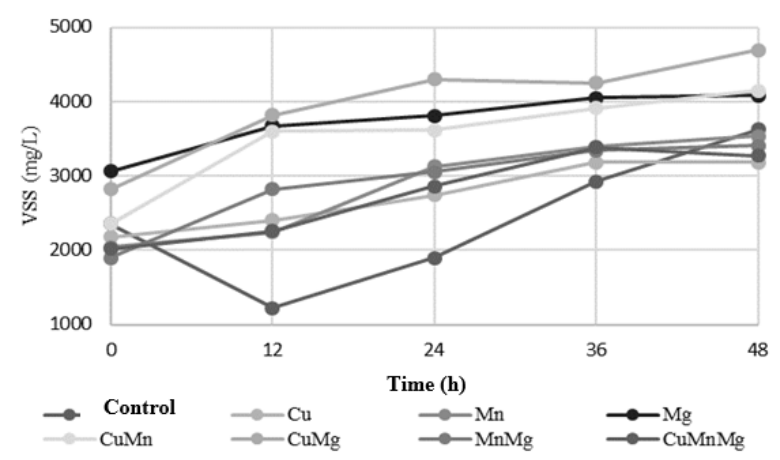

Fig. 3. VSS Values in running reactor 
In the beginning of running reactor, The VSS values of $1,800-3,100 \mathrm{mg} / \mathrm{L}$. VSS values tend to increase at each sampling time eventhough not too significant. The VSS values at $48 \mathrm{~h}$ of $3,200-4,700 \mathrm{mg} / \mathrm{L}$.

COD concentration for each variation tend to decrease. In the beginning of running reactor, the COD concentration of $5,100-7,800 \mathrm{mg} / \mathrm{L}$ and in the final of running reactor (at 48 hours), the COD concentration of

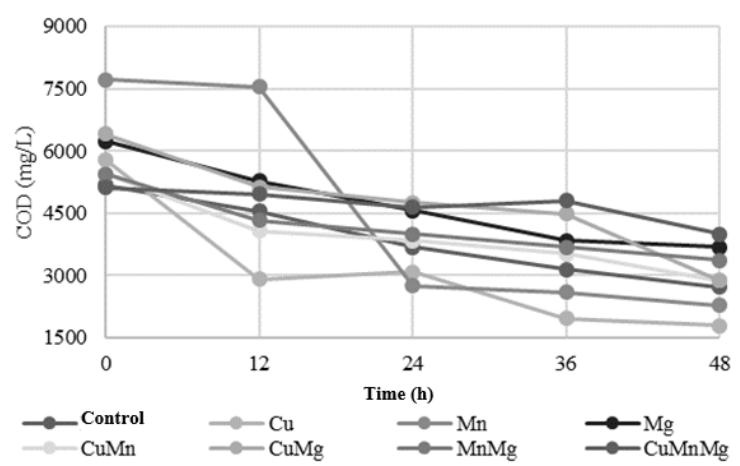

Fig. 4. COD concentration in running reactor

1,800-4,000 mg/L. The decreasing of COD concentration shows that organic content in substrate has converted into different substances, such as ethanol, TVA, and other gaseous products. COD concentration for each variation can be seen in Fig. 4.

\subsection{Screening for significant effects of trace element on ethanol formation based on two-way level factorial design}

Statistical analysis in this study using the statistical analysis of two-way level factorial design. This analysis aims to see the influence of each factor on every level, and estimate at the interaction between factors that affect the formation of ethanol. Statistical test is compared with the value of $F_{\text {table }}$ at a significance level of $5 \%$ and $1 \%$ with the following hypotheses:

$$
\begin{aligned}
& \mathrm{H}_{0}: \mu 1=\mu 2=\mu 3 \\
& \mathrm{H}_{1}: \mu 1 \neq \mu 2 \neq \mu 3
\end{aligned}
$$

$\mathrm{H}_{0}$ fail to reject if the significance of $\mathrm{F}<\mathrm{F}_{\text {table }}(5 \%)$ and $\mathrm{F}<\mathrm{F}_{\text {table }}(1 \%)$, which is the conclusion there is no significant effects between the mean of each population. It means that there is no significant effect on ethanol formation of various variables tested.

$\mathrm{H}_{0}$ reject if the significance of $\mathrm{F}>\mathrm{F}_{\text {table }}(5 \%)$ and $\mathrm{F}>\mathrm{F}_{\text {table }}$ $(1 \%)$, which is the conclusion there is a significant difference between the mean of each population. It means that there is a significant effect on ethanol formation of various variables tested.

Variations in this study correspond to the combination treatment is needed. The result of ethanol formation at the end of the process can be seen in Table 7. The results of calculations using statistical analysis $2^{\mathrm{n}}$ method at various metal additions can be seen in Table 8.

Based on the result of two factors ANOVA test, $\mathrm{H}_{0}$ on the $\mathrm{C}$ and $\mathrm{AB}$ variations were rejected, that meaning these factors at various levels had a significant effect on ethanol formation.

Table 7. Experimental values of ethanol concentration in

\begin{tabular}{|c|c|c|c|c|}
\hline \multicolumn{3}{|c|}{ Factor } & \multicolumn{2}{|c|}{$\begin{array}{c}\text { Ethanol concentration } \\
\qquad(\mathrm{mg} / \mathrm{L})\end{array}$} \\
\hline $\mathrm{C}(\mathrm{Mg})$ & B (Mn) & $\mathrm{A}(\mathrm{Cu})$ & R1 & $\mathrm{R} 2$ \\
\hline \multirow{4}{*}{0} & \multirow{2}{*}{0} & 0 & 3741.53 & 3741.53 \\
\hline & & 0.1 & 3741.53 & 1870.77 \\
\hline & \multirow{2}{*}{3} & 0 & 7483.07 & 7483.07 \\
\hline & & 0.1 & 7483.07 & 5612.30 \\
\hline \multirow{4}{*}{0.05} & \multirow{2}{*}{0} & 0 & 3741.53 & 1870.77 \\
\hline & & 0.1 & 5612.30 & 3741.53 \\
\hline & \multirow{2}{*}{3} & 0 & 3741.53 & 3741.53 \\
\hline & & 0.1 & 7483.07 & 5612.30 \\
\hline
\end{tabular}
variations addition of metals.

Table 8. The results of calculations two-way level factorial

\begin{tabular}{|c|c|c|c|c|}
\hline Variation & $\mathbf{F}$ & $F_{\text {table }} 5 \%$ & $F_{\text {table }} 1 \%$ & Result \\
\hline 1 & 784.47 & 5.59 & 12.25 & $\mathrm{H}_{0}$ reject \\
\hline $\mathrm{a}$ & 4.20 & 5.59 & 12.25 & $\begin{array}{c}\mathrm{H}_{0} \text { fail to } \\
\text { reject }\end{array}$ \\
\hline b & 56.47 & 5.59 & 12.25 & $\mathrm{H}_{0}$ reject \\
\hline$a b$ & 0.47 & 5.59 & 12.25 & $\begin{array}{c}\mathrm{H}_{0} \text { fail to } \\
\text { reject }\end{array}$ \\
\hline $\mathrm{c}$ & 4.20 & 5.59 & 12.25 & $\begin{array}{c}\mathrm{H}_{0} \text { fail to } \\
\text { reject }\end{array}$ \\
\hline $\mathrm{ac}$ & 22.87 & 5.59 & 12.25 & $\mathrm{H}_{0}$ reject \\
\hline $\mathrm{bc}$ & 11.67 & 5.59 & 12.25 & $\begin{array}{c}\mathrm{H}_{0} \text { fail to } \\
\text { reject }\end{array}$ \\
\hline
\end{tabular}
design. 


\begin{tabular}{|c|c|c|c|c|}
\hline $\mathrm{abc}$ & 0.47 & 5.59 & 12.25 & $\begin{array}{c}\text { Ho fail to } \\
\text { reject }\end{array}$ \\
\hline Error & - & - & - & - \\
\hline Total & - & - & - & - \\
\hline
\end{tabular}

Variation 1 was a variation without the addition of metal ions. The hypothesis in this variation is reject, which concludes that factors had a significant effect on ethanol formation. In other words, the absence of any additional metal forming process of ethanol can occur naturally.

$\mathrm{Mn}^{2+}$ and $\mathrm{Cu}^{2+} ; \mathrm{Mg}^{2+}$ combination are screened as the significant variable which had positive effects on ethanol formation from POME at a significance level of 5\% and $1 \%$.

\subsection{Screening for significant effects of trace element on TVA formation based on two-way level factorial design}

Statistical analysis in this study using the statistical analysis of two-way level factorial design. This analysis aims to see the influence of each factor on every level, and estimate at the interaction between factors that affect the formation of TVA. Statistical test is compared with the value of $\mathrm{F}_{\text {table }}$ at a significance level of $5 \%$ and $1 \%$ with the following hypotheses.

$$
\begin{aligned}
& \mathrm{H}_{0}: \mu 1=\mu 2=\mu 3 \\
& \mathrm{H}_{1}: \mu 1 \neq \mu 2 \neq \mu 3
\end{aligned}
$$

$\mathrm{H}_{0}$ fail to reject if the significance of $\mathrm{F}<\mathrm{F}_{\text {table }}(5 \%)$ and $\mathrm{F}<\mathrm{F}_{\text {table }}(1 \%)$, which is the conclusion there is no significant effects between the mean of each population. It means that there is no significant effect on TVA formation of various variables tested.

$\mathrm{H}_{0}$ reject if the significance of $\mathrm{F}>\mathrm{F}_{\text {table }}(5 \%)$ and $\mathrm{F}>\mathrm{F}_{\text {table }}$ $(1 \%)$, which is the conclusion there is a significant difference between the mean of each population. It means that there is a significant effect on TVA formation of various variables tested.

Variations in this study correspond to the combination treatment is needed. The result of TVA formation at the end of the process can be seen in Table 9. The results of calculations using statistical analysis $2^{\mathrm{n}}$ method at various metal additions can be seen in Table $\mathbf{1 0}$.

Based on the result of two factors ANOVA test, $\mathrm{H}_{0}$ on the $b$ and $c$ variations were rejected, that meaning these factors at various levels had a significant effect on TVA formation.

Volatile acid is the main product of organic material degradation at acidogenesis phase under anaerobic process. Volatile acids as acetic acid is the substrate that should be converted by methanogenic bacteria into methane and carbon dioxide. TVA concentration is closely related to the acidogenesis process because the increase of total volatile acids formation.
Table 9. Experimental values of TVA concentration in

\begin{tabular}{|c|c|c|c|c|}
\hline \multicolumn{3}{|c|}{ Factor } & \multicolumn{2}{|c|}{$\begin{array}{c}\text { TVA concentration } \\
(\mathrm{mg} / \mathrm{L})\end{array}$} \\
\hline $\mathrm{C}(\mathrm{Mg})$ & B (Mn) & $\mathbf{A}(\mathrm{Cu})$ & R1 & $\mathrm{R} 2$ \\
\hline \multirow{4}{*}{0} & \multirow{2}{*}{0} & 0 & 960 & 1056 \\
\hline & & 0.1 & 1056 & 1152 \\
\hline & \multirow{2}{*}{3} & 0 & 1536 & 1440 \\
\hline & & 0.1 & 1152 & 1440 \\
\hline \multirow{4}{*}{0.05} & \multirow{2}{*}{0} & 0 & 1536 & 1728 \\
\hline & & 0.1 & 1152 & 1536 \\
\hline & \multirow{2}{*}{3} & 0 & 1536 & 1728 \\
\hline & & 0.1 & 1440 & 1536 \\
\hline
\end{tabular}
variations addition of metals.

Table 10. The results of calculations two-way level factorial design.

\begin{tabular}{|c|c|c|c|c|}
\hline Variation & $\mathbf{F}$ & $\mathbf{F}_{\text {table }} \mathbf{5 \%}$ & $\mathbf{F}_{\text {table 1\% }}$ & Result \\
\hline 1 & 2890.45 & 5.59 & 12.25 & $\mathrm{H}_{0}$ reject \\
\hline $\mathrm{a}$ & 6.67 & 5.59 & 12.25 & $\mathrm{H}_{0}$ fail to reject \\
\hline $\mathrm{b}$ & 15.93 & 5.59 & 12.25 & $\mathrm{H}_{0}$ reject \\
\hline $\mathrm{ab}$ & 0.50 & 5.59 & 12.25 & $\mathrm{H}_{0}$ fail to reject \\
\hline $\mathrm{c}$ & 34.45 & 5.59 & 12.25 & $\mathrm{H}_{0}$ reject \\
\hline $\mathrm{ac}$ & 2.70 & 5.59 & 12.25 & $\mathrm{H}_{0}$ fail to reject \\
\hline $\mathrm{bc}$ & 6.67 & 5.59 & 12.25 & $\mathrm{H}_{0}$ fail to reject \\
\hline
\end{tabular}




\begin{tabular}{|c|c|c|c|c|}
\hline $\mathrm{abc}$ & 4.46 & 5.59 & 12.25 & $\mathrm{H}_{0}$ fail to reject \\
\hline Error & - & - & - & - \\
\hline Total & - & - & - & - \\
\hline
\end{tabular}

Variation 1 was a variation without the addition of metal ions. The hypothesis in this variation is reject, which concludes that factors had a significant effect on ethanol formation. In other words, the absence of any additional metal forming process of ethanol can occur naturally. $\mathrm{Mn}^{2+}$ and $\mathrm{Cu}^{2+} ; \mathrm{Mg}^{2+}$ combination are screened as the significant variable which had positive effects on ethanol formation from POME at a significance level of $5 \%$ and $1 \%$.

\subsection{The comparison of two-way level factorial design results on ethanol and TVA formation}

The comparison of two-way level factorial design results on ethanol and TVA formation can be seen in Table 11. The difference of results may indicate predisposition of the metal ions to form a product. In addition, the switching material to other products may occur during the process.

Table 11. The comparison of two-way level factorial design results on ethanol and TVA formation.

\begin{tabular}{|c|c|c|c|}
\hline \multicolumn{2}{|c|}{ Variations } & $\begin{array}{c}\text { TVA } \\
\text { Formation }\end{array}$ & $\begin{array}{c}\text { Ethanol } \\
\text { Formation }\end{array}$ \\
\hline 1 & Control & $\mathrm{H}_{0}$ reject & $\mathrm{H}_{0}$ reject \\
\hline $\mathrm{A}$ & $\mathrm{Cu}$ & $\begin{array}{c}\mathrm{H}_{0} \text { fail to } \\
\text { reject }\end{array}$ & $\begin{array}{c}\mathrm{H}_{0} \text { fail to } \\
\text { reject }\end{array}$ \\
\hline $\mathrm{B}$ & $\mathrm{Mn}$ & $\mathrm{H}_{0}$ reject & $\mathrm{H}_{0}$ reject \\
\hline $\mathrm{AB}$ & $\mathrm{CuMn}$ & $\begin{array}{c}\mathrm{H}_{0} \text { fail to } \\
\text { reject }\end{array}$ & $\begin{array}{c}\mathrm{H}_{0} \text { fail to } \\
\text { reject }\end{array}$ \\
\hline $\mathrm{C}$ & $\mathrm{Mg}$ & $\begin{array}{c}\mathrm{H}_{0} \text { reject } \\
\text { reject }\end{array}$ & $\begin{array}{c}\mathrm{H}_{0} \text { fail to } \\
\text { reject }\end{array}$ \\
\hline $\mathrm{AC}$ & $\mathrm{CuMg}$ & $\begin{array}{c}\mathrm{H}_{0} \text { fail to } \\
\text { reject }\end{array}$ & \begin{tabular}{c}
$\mathrm{H}_{0}$ reject \\
\hline $\mathrm{BC}$
\end{tabular} \\
\hline $\mathrm{MnMg}$ & $\begin{array}{c}\mathrm{H}_{0} \text { fail to } \\
\text { reject }\end{array}$ & $\begin{array}{c}\mathrm{H}_{0} \text { fail to } \\
\text { reject }\end{array}$ \\
\hline $\mathrm{ABC}$ & $\mathrm{CuMnMg}$ & $\begin{array}{c}\mathrm{H}_{0} \text { fail to } \\
\text { reject }\end{array}$ & $\begin{array}{c}\mathrm{H}_{0} \text { fail to } \\
\text { reject }\end{array}$ \\
\hline
\end{tabular}

\section{Conclusions}

High levels of organic contents in POME can be reduced by anaerobic treatment. Wastewater treatment with high concentration of organic can be treated by the suspended growth in anaerobic reactors. $\mathrm{pH}$ values, COD removal, and biomass growth, were analyzed as process control in running reactor. The $\mathrm{pH}$ values during operation has an important role to determine the composition of the acidogenesis effluent in the reactor. Acidogenesis phase in this study occur until the $36^{\text {th }}$ hour. Based on screening experiments, $\mathrm{Mn}^{2+}$ and $\mathrm{Cu}^{2+}, \mathrm{Mg}^{2+}$ metal ions combination are screened as the significant variable which had positive effects on ethanol formation and $\mathrm{Mg}^{2+}$ and $\mathrm{Mn}^{2+}$ metal ions were screened as the significant variable which had positive effects on TVA formation from POME at a significance level of 5\% and $1 \%$. The difference of results may indicate predisposition of the metal ions to form a product. In addition, the switching material to other products may occur during the process.

\section{References}

1. D. Andrio, Mechanism and Strategy Control for Ethanol Formation as a High Organic Content Wastewater Recycle. Doctoral Dissertation. Environmental Engineering, ITB. Bandung. (2014)

2. M. Azenha, M.T. Vasconcelos, and P. MoradasFerreira, The influence of $\mathrm{Cu}$ concentration on ethanolic fermentation by Saccharomyces cerevisiae. J. Biosci. Bioeng. 90, 163-167. (2000)

3. W. Cao, R. Liu, Screening and optimization of trace elements supplement in sweet sorghum juice for ethanol production. Biomass and bioenergy 50 (2013) 45-51. (2012)

4. C.A. Chernicaro, de Lemos. Biological Wastewater Treatment Series Volume Four: Anaerobic Reactors. IWA Publishing: London, UK. (1997)

5. D. Diviana, Effect of Fe, Mn and Ni Metals in The Formation of Ethanol from Degradation Process of Waste of Cocoa Pulp in Anaerob Condition. Undergraduate Thesis. Environmental Engineering, ITB, Bandung. (2014)

6. M.H. Gerardi, Microbiology of Anaerobic Digesters. John Wiley Sons, New Jersey. (2003)

7. G. Gottschalk, S. Peinemann, The anaerobic way of life. In: Balows A et al. (eds) The Prokaryotes, pp. 300-311. Berlin: SpringerVerlag. (1992)

8. A. Gumilar, Effect of Flushing $N_{2}$ and Variations the Addition of $\mathrm{Fe}^{2+}, \mathrm{Zn}^{2+}$ for Ethanol and Acidogenesis Products Formation in Degradation Process of High Organic Wastewater Under Anaerobic Condition. Postgraduate Thesis. Environmental Engineering, ITB, Bandung. (2016)

9. M.A.B. Habib, F.M. S.M. Yusoff, K.J. Phang, S. Mohamed, Nutritional values of chironomid larvae grown in palm oil mill effluent and algal culture. Aquaculture, 158: 95-105. (1997)

10. A.N. Ma, Environmental Management for the Oil Palm Industry. Palm Oil Dev., 30: 1-10. (2000)

11. S. Onuki, J. A. Koziel, W.S. Jenks, J. van Leeuwen, D.A Greewell, Ethanol production, purification, and 
analysis techniques a review. ASABE Annual International Meeting. Paper Number: 085136. USA. (2008)

12. D.H. Prakoso, Effect of Flushing $\mathrm{N}_{2}$ and Variations the Addition of $\mathrm{Fe}^{2+}$ for Ethanol Formation in Degradation Process of High Organic Wastewater Under Anaerobic Condition. Undergraduate Thesis. Environmental Engineering, ITB, Bandung. (2015)

13. M. Perez, L.I. Romero, D. Sales, Organic matter degradation kinetics in an anaerobic thermophilic fluidised bed bioreactor. Anaerobe, 7: 25-35. (2001)

14. Pusat Data dan Informasi Departemen Perindustrian. Gambaran Sekilas Industri Minyak Kelapa Sawit. Jakarta: Departemen Perindustrian. (2007)

15. J. Saxena, R.S. Tanner, Effect of Trace Metals on Ethanol Production from Synthesis Gas by the Ethanologenic Acetogen, Clostridium ragsdalei. ASM Press, Washington, DC, pp 147-151. (2010)

16. P.K. Shin, M.H. Kim, J.H. Kim, Biodegradability of degradable plastic exposed to anaerobic digested sludge and simulated landfill conditions. J. Environ. Polym. 5, 1, 33-39. (2001)

17. S. Sinnaraprasa, P. Fongsatitkul, Optimal Condition of Fenton's Reagent to Enhance the Alcohol Production from Palm Oil Mill Effluent (POME). Environment Asia 4(2) (2011) 9-16. (2011)

18. G. Tchobanoglous, F. L. Burton, Wastewater Engineering: Treatment, Disposal, and Reuse. McGraw-Hill: Singapore. (1991)

19. World Growth. Laporan World Growth: Manfaat Minyak Sawit bagi Perekonomian Indonesia. (2011)

20. O. Deesuth, P. Laopaiboon, P. Jaisil, L. Laopaiboon, Optimization of Nitrogen and Metal Ions Supplementation for Very High Gravity Bioethanol Fermentation from Sweet Sorghum Juice Using an Orthogonal Array Design. J Energies 5, 3178-3197. (2012)

21. Y. Shen, H. Zhang, X. Zheng, X. Zhang, J. Guo, Y. Chen, Very high gravity fermentation using sweet potato for fuel ethanol production. Adv Mat Res. 2011:236-238:59-62. (2011) 